\title{
GENETIC DIFFERENTIATION AMONG POPULATIONS OF Chromobotia macracanthus BLEEKER FROM SUMATRA AND KALIMANTAN BASED ON SEQUENCING GENE OF MTDNA CYTOCHROME B AND NUCLEUS DNA RAG2
}

\author{
Sudarto"), Kafi Hidonis ${ }^{* *}$, and Emmanuel Paradis ${ }^{* * *}$
}

\begin{abstract}
Research on genetic differentiation among populations of Chromobotia macracanthus Bleeker from Sumatra, based on sequencing gene of mtDNA Cytochrome b and nucleus DNA RAG2 has been done. The objectives of the study were to obtain the representation of genetic differentiation among population of clown loach fishes or botia (Chromobotia macracanthus) from Sumatra and Kalimantan and to estimate the time divergence of both population group of botia. Samples of botia population were taken from 3 rivers in Sumatra namely Batanghari, Musi, and Tulang Bawang and one river from Kalimantan namely Kapuas. The genetic analysis was based on the sequencing of mtDNA Cytochrome $b$ and nucleus DNA RAG2. The statistical analysis was done by using APE package on R language. The parameters observed were: nucleotide diversity, genetic distance, and neighbor-joining tree. The result showed that the highest nucleotide diversity was fish population of Musi, while the other two populations, Tulang Bawang (Sumatra) and Kapuas (Kalimantan), were considered as the lowest genetic diversity especially based on nucleus DNA RAG2 sequencing. Based on mtDNA Cytochrome-b sequencing, the most distinct population among those populations based on genetic distance were fish populations of Musi and Kapuas. According to the result of neighbor-joining tree analysis, the populations of botia were classified into two groups namely group of Sumatra and group of Kalimantan. The estimation of time divergence among group of population of Sumatra and Kalimantan based on mtDNA Cytochrome b was about 9.25-9.46 million years (Miocene era). The high genetic differences between groups of Sumatra and Kalimantan suggested that the effort of restocking botia from Sumatra into Kalimantan has to be done carefully, because it may disturb the gene originality of both botia populations.
\end{abstract}

KEYWORDS: botia, Cytochrome-b, RAG2, APE, R-program

\section{INTRODUCTION}

Botia (Chromobotia macracanthus Bleeker) known as clown loach fish is one of economically important species of freshwater ornamental fishes. Botia is an indigeneous species to Indonesian waters especially in Batanghari, Musi, and Kapuas River (Kottelat et al., 1993).
The increase of botia fish demand as ornamental fish causes the increase of human activity around the river, like fishing on botia population from juvenile to adult. Environmental changes due to the increase of development activity cause a decrease in botia population. In Kapuas River for example, the low

\footnotetext{
") Research Institute for Freshwater Ornamental Fish Culture Depok, Indonesia

**) Faculty of Marine Science and Fisheries, IPB Bogor

***) Institut de Recherches pour le Dévelopment (IRD), Indonesia - France
} 
level composition and abundance of fish (including botia) have not only been affected by fishing activity, but also by the pollution resulted from peat land development activity (Harteman, 1998). The efforts for preserving this population such as conservation, restocking, cultivation, and domestication are needed. Nevertheless the cultivation of botia until now is still in laboratory scale, as it has been done by LRBIHAT-DKP in cooperation with Institut de Recherche pour le Developpement (IRD)France.

Classification of Chromobotia macracanthus according to Weber \& Beaufort (1916); Kottelat (2004) and Šlechtová et al. (2006) is as follows:

Kingdom : Animalia

Phylum : Chordata

Class : Pisces

Subclass: Teleostei

Order : Ostariophysi

Suborder: Cyprinoidea

Family : Cobitidae

Genus : Chromobotia

Species : Chromobotia macracanthus Bleeker
The common name of Chromobotia macracanthus is clown loach. In Indonesia it is known as botia. It also has local name such as ikan macan (Sumatra); gecuban (Lampung); biju bana (Jambi), and langli (Mahakam River, Kalimantan) (Weber \& Beafourt, 1916).

Morphologically, botias have orange color body with 3 black bars. Its eyes are not covered with skin as shown on the picture (Kottelat et al., 1993). According to Wirasatya (1994), the populations of botia in Batanghari and in Kapuas showed morphological difference. Botia from Kalimantan (Figure 1) has brighter colour than that of Sumatra (Figure 2).

Different varieties of color can represent different species as shown in a case of different varieties of color of the asian arowana (Scleropages formosus) (Pouyaud et al., 2003).

The efforts of preserving botia population still need more information on ecobiological characteristics of botia population in order to achieve a successful management. According to Wirasatya (1994), the populations of botia in Batanghari and in Kapuas showed morphological differences especially on the color appearance. The color of botia from Kapuas River

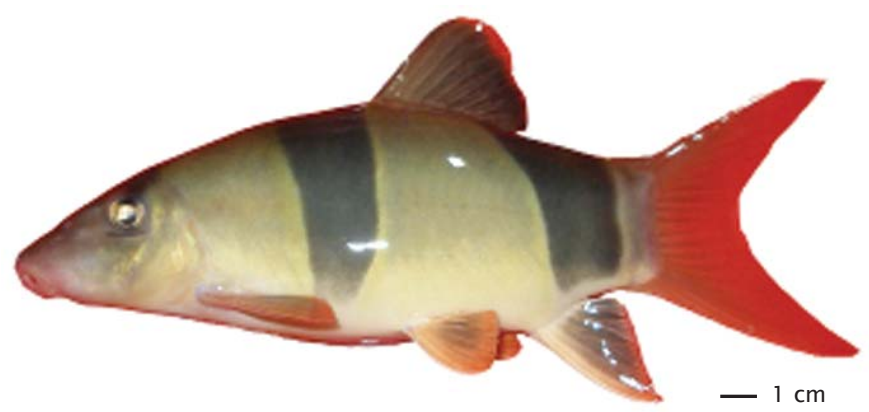

Figure 1. Chromobotia macracanthus Bleeker of Kalimantan

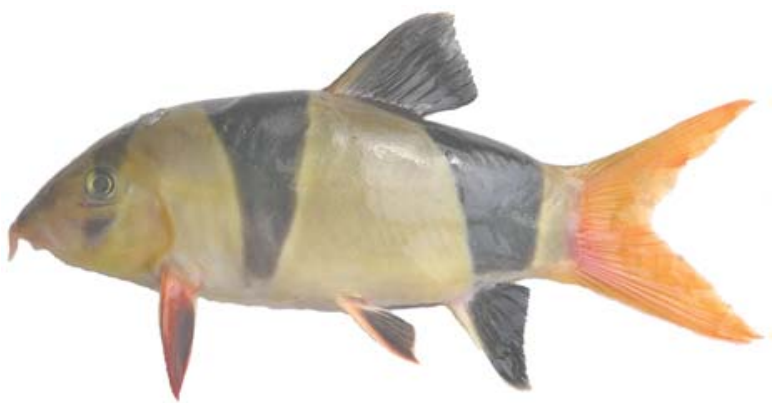

Figure 2. Chromobotia macracanthus Bleeker of Sumatra 
(West Kalimantan) looks brighter than that of botia from Batanghari River. Fish population genetics have important roles in either fisheries management program or production. The genetic variability is an essential key for the survival of a species for next generations to come. The conservation of genetic diversity has become a primary concern for IUCN (International Union for Conservation of nature and Natural Resources). Concerning botia population, information on the genetic aspects is still limited. To maintain the sustainability of botia population in Indonesia, especially in Sumatra and Kalimantan, research on genetic aspects of botia population is important to be carried out.

The increasing of fishing activity and habitat destruction cause the degradation of genetic population diversity. Therefore, control and evaluation on botia population are needed to keep its genetic diversity.

Efforts to maintain botia population, such as restocking and domestication have to be conducted. Due to unclear information whether populations of botia from Sumatra and Kalimantan are genetically similar, careful manipulation of botia population either for restocking or farming is essential, because it will risk disturbing the genetic of original population. Therefore research on genetics of botia populations from Sumatra and Kalimantan is required to provide more information needed for its conservation and management.
Cytochrome $b$ is one of mitochondrial DNA's. Cytochrome $b$ analysis is often used in fisheries to figure out genetic diversity of a population because it is more sensitive than protein analysis and generally used to study phylogeography (Baker, 2000).

RAG2 is one of genes on nucleus. RAG2 encodes some enzymes that have important role in gene sequencing. RAG2 analysis is often used in studying phylogeny on teleostei fish (Sullivan et al., 2000).

Mitochondrial DNA is one of the genomes in somatic cell. It is small in size, rounded and simpler than the gene in nucleus cell, and able to do self replication (Baker, 2000). mtDNA has a role in encoding some of tRNA, rRNA, and proteins that are used in protein synthesis in mitochondria (Griffiths et al., 2000). The size of mtDNA is less than $20 \mathrm{~kb}$ and it is inherited through female ancestor. All mtDNA's have many genes that encode protein enzym in respiratory such as: D-loop, cytochrome b, NADH 1-7, NADH-41, cytochrome c oxidase (COX-1-3), ATP 6;8;9, 12 s rRNA, 16s RNA, and tRNA (Figure 3).

The differences between mtDNA gene and nucleus gene include 2 factors. First, mtDNA inherit maternally (from female ancestor). It does not follow the mendellian's law. Second, mtDNA is haploid and mutation rate of mtDNA is 5--10 times faster than nucleus gene. The average divergence rate of mtDNA in vertebrate is 1\%--

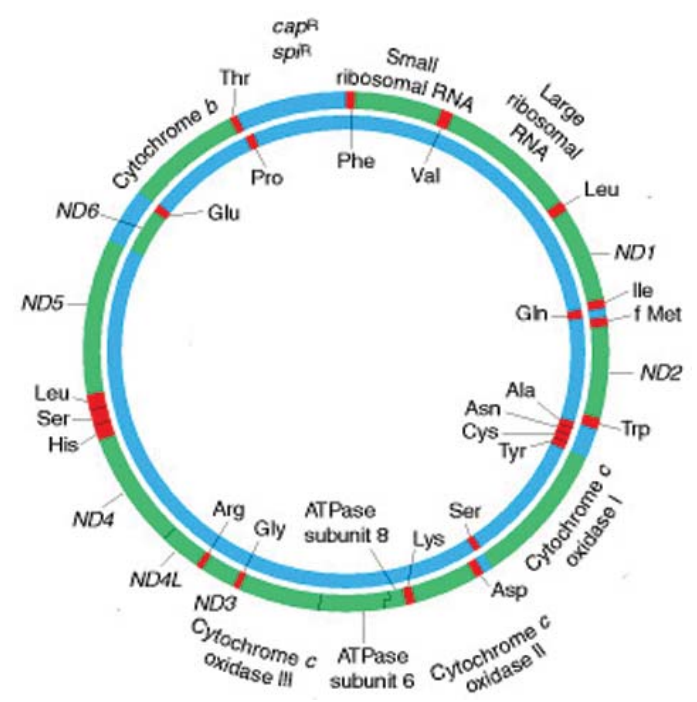

Figure 3. Human's mtDNA map (Lemire, 2005) 
$2 \%$ per million years (Randi, 2000). The increase of mutation rate on mtDNA is caused by environmental factors or mutations in nucleus gene that affect mtDNA (Lemire, 2005).

Cytochrome $b$ is part of mtDNA. It is one of cytochromes that has role in mitochondria respiratory. Cytochrome b is commonly used in phylogenetic study, because it has enough variable in population level (Oulu, 2000). Cytochrome $b$ is also generally used in phylogeographic studies. Doadrio \& Perdices (2005) who developed time divergence for Cobitis (family: Cobitidae) based on the Cytochrome b gene had $0.68 \%$ per pairwise per 1 million year. The location of Cytochrome $b$ on Chromobotia macracanthus is 14380-15516 bp (NCBI, 2007).

RAG is one of genes in the nucleus. RAG encodes some enzymes that have important role in gene sequencing of immunoglobulin and $T$ molecule during VDJ recombination. RAG2 is very important for lymphocyte $B$ and $\mathrm{T}$; both of them are the essential components in body immune. RAG enzyme works as a complex sub unit that affect fission in double helix DNA molecule. RAG protein has many elements, such as RAG 2 in mouse consists of 527 amino acids. The enzymatic activity in RAG is centralized in nucleus and the rest of RAG2 obstruct most of DNA fission activities (Wikipedia, 2007).

Biogeography is a study of organism distribution through space and time (Wiley, 1981).
Modern biogeography started since 1960, at the same time the tectonic plate theory was developed. So it has important role in biogeography concepts.

Modern biogeography relates with dispersal and vicariance theory. Dispersal theory considers that ancestor population zone was bordered by geographical obstructions, then that border were passed by some members of the population. If those members successeded in growing up on the new area, they will be included in different taxa. Vicariance theory on the other hand considers that ancestor population was divided in several sub populations when barrier appeared, which means its population could not cross it. Then, those different sub populations grown into different taxas.

Rainboth (1991) in Gustiano (2003) said that the fauna of Perak river in the west side of Malayan peninsula has relationship with the fauna in North Sumatra. The fauna in the center of Sumatra is similar to the fauna in Kapuas (Kalimantan).

In the pleistocene era, India, Malayan peninsula and all islands on the Sunda shelf, Kalimantan, Sumatra, Java were connected when the sea level down. The continent was a crossed by several river systems and its streams (de Beaufort, 1951 in Gustiano, 2003).

Kottelat (1993) explained that Sunda shelf (20--40 meter under sea level) was a large land

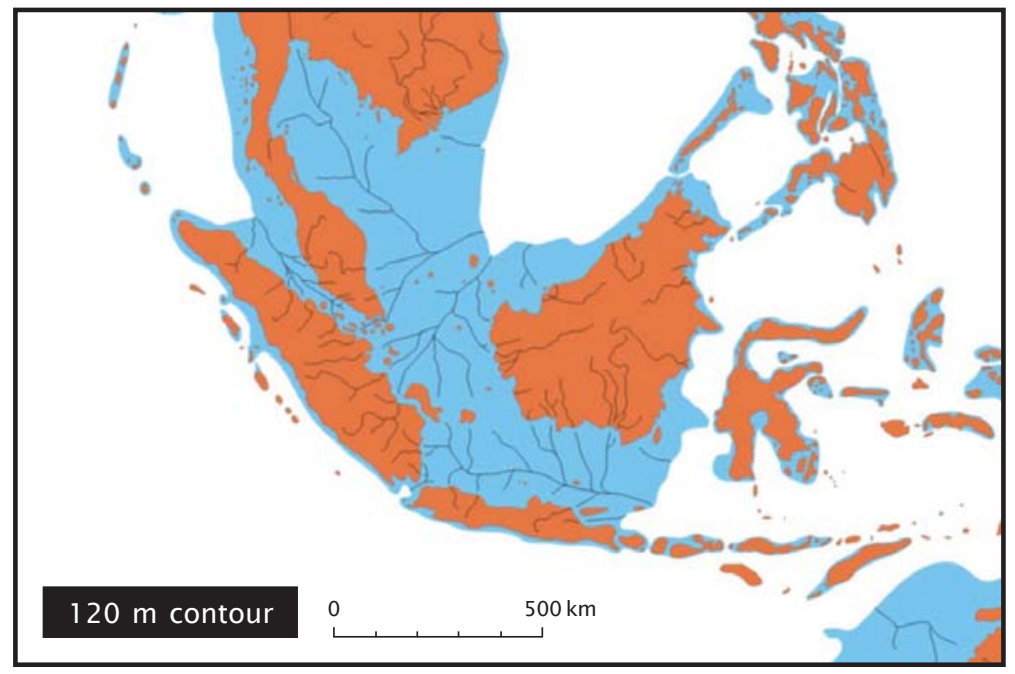

Figure 4. Ancient rivers in South East Asia at pleistocene (Voris, 2000) 
mass and there were three main rivers flowing across on it from Malaya, Sumatra, Borneo, and Java to South China Sea. Batanghari River, Musi River and Kapuas River joined into one primary river to South China Sea (Figure 4).

In fisheries resource management, population genetic structure of fish has become a very serious concern especially in the case of fish ability facing on immeasurable ecological pressure. Immeasurable progressive genetic variations owned by fish is enabling fish to survive in a long time because of its adaptation ability to various environmental changes. High genetic variations means that fish has many genes that allow it to cope with environmental changes, while low genetic variation means that less genes to cope with environmental change (Soewardi, 2007).

According to Dunham (2004), genetic variation is important to the survival of a species. Dunham (2004) said that genetic variation can ascertain fitness of a population or species regarding its adaptation to environmental changes. According to Rina (2001), genetic variation can influence population response to selection, both natural and artificial selections.

\section{Objective}

The objectives of this research were to obtain the representation of genetic differentiation between population of botia from Sumatra (Batanghari, Tulang Bawang, and Musi) and Kalimantan (Kapuas), and to estimate time divergence between both population groups.

It is hoped that this research will give an essential information on the management efforts in maintaining the sustainability of botia population and other related activities such as domestication, aquaculture, and conservation and restocking in the future.

\section{MATERIALS AND METHODS}

The research was conducted at Biological and Nutrition Laboratory of Loka Riset Budidaya Ikan Hias Air Tawar Depok, Departement of Marine Affairs and Fisheries of Indonesia.

Botia samples were collected from Sumatra (Batanghari, Tulang Bawang, Musi Rivers) and Kalimantan (Kapuas River), five samples were taken from each location.

Lab analysis consisted of: DNA extraction, PCR amplification, electrophoresis, DNA estimation, DNA purification, and DNA sequencing.

\section{Data Analysis}

Data analysis was done by calculating DNA fragments from each restriction based on DNA fragment type using APE packages on $R$ language (Paradis et al., 2004). Based on that calculation, then it was able to estimate the haplotype diversity and genetic distance intra and inter populations.

\section{Nucleotide diversity}

The analysis of nucleotide diversity was performed by calculating haplotype frequencies inter populations using APE (Paradis et.al., 2004) based on Nei's formula (1987) :

$$
\pi=\frac{\Sigma X i}{n(n-1) / 2}
$$

Where:

$$
\begin{aligned}
& \pi=\text { nucleotide diversity } \\
& \mathrm{Xi}=\text { different sequence frequencies } \\
& \mathrm{n}=\text { number sequence }
\end{aligned}
$$

\section{Genetic distance (Genetic Distance, D)}

Genetic distance represents measured size of the genetic differences among populations. The calculation of genetic distance was based on Kimura (1980) using APE program (Paradis et al., 2004), with formula:

$$
d=1 / 2 \ln (1-2 P-Q)-1 / 4 \ln (1-2 Q)
$$

Where:

$\mathrm{d}=$ genetic distance

$\mathrm{P}=$ proportion of transition on sequence

$\mathrm{Q}=$ proportion of transversion on sequence

\section{Neighbor-joining tree}

The neighbor-joining tree was reconstructed in order to show the phylogeny tree (relationship tree). The distance among each branches represents the genetic distance. The neighbor joining tree based on Saitou \& Nei (1987) was done by using APE (Paradis et al., 2004).

\section{RESULTS AND DISCUSSION}

\section{Nucleotide Diversity}

The result of nucleotide sequencing of mtDNA Cytochrome $b$ and nucleus DNA RAG2 of Chromobotia macracanthus showed that the total length of sequence was about 1137 bp for Cytochrome b, and 1232 bp for RAG2. 
The nucleotide composition as a result of the sequencing is presented in Table 1.

The nucleotide compositions of Cytochrome $b$ were not balanced, where the nucleotide A (Adenine) on Cytochrome $b$ has the biggest composition $(30,54 \%)$, while nucleotide $\mathrm{G}$ (Guanine) has the smallest composition $(14,14 \%)$ (Table 3). Whereas nucleotide composition of RAG2 was relatively balance (nearly the same) with the composition of nucleotide $\mathrm{G}$ (Guanine) was slightly bigger $(25,49 \%)$ than the other nucleotide.

Nucleotide diversity calculated using APE (Paradis et al., 2004) is presented in Table 2.

Population of Musi has the highest nucleotide diversity $(0.0026385224$ on mtDNA Cytochrome $b$ and 0.0006493506 on nucleus DNA RAG2) than other populations. Similarly, population of Musi has also the highest diversity based on nucleus DNA RAG2 sequencing. While for the other two populations namely Tulang Bawang and Kapuas, their nucleotide diversity based on nucleus DNA RAG2 sequencing were homogen.

\section{Genetic Distance Based on mtDNA Gen Cytochrome b}

The Kimura (1980) genetic distances of botia populations calculated using APE (Paradis et al., 2004) of mtDNA Cytochrome b are presented in Table 3.

The average genetic distance of Chromobotia macracanthus was about 0.026290 . The longest genetic distance was between Musi and Kapuas population (0.0643429202) as shown in Table 3.

\section{Neighbor-joining tree Based on mtDNA Gene Cytochrome b}

Genetic distance on mtDNA Cytochrome $b$, the neighbor-joining tree was constructed by using APE program (Paradis et al., 2004). The neighbor-joining tree based on mtDNA Cytochrome $b$ is presented in Figure 5.

Based on Neighbor-joining Chromobotia macracanthus tree showed that population of botia was divided into two groups, namely group of Sumatra and group of Kalimantan.

\section{Genetic Distance Based on Nucleus DNA RAG2}

The genetic distance that was calculated according to Kimura (1980) using APE program (Paradis et al., 2004) based on Nucleus DNA RAG2 is shown on Table 4.

The genetic distance based on Nucleus DNA RAG2 gave clearer information that botia populations from Sumatra and Kalimantan are

Table 1. Nucleotide fragment composition on Cytochrome$b$ dan RAG 2

\begin{tabular}{lcccc}
\hline \multirow{2}{*}{ DNA } & \multicolumn{4}{c}{ Nucleotide fragment } \\
\cline { 2 - 5 } & A & C & G & T \\
\hline Cytochrome- $\boldsymbol{b}$ & $30,54 \%$ & $27,04 \%$ & $14,14 \%$ & $28,28 \%$ \\
RAG2 & $24,81 \%$ & $25,31 \%$ & $25,49 \%$ & $24,39 \%$ \\
\hline
\end{tabular}

Table 2. Nucleotide diversity on Chromobotia macracanthus population

\begin{tabular}{lrr}
\hline \multirow{2}{*}{ Population } & \multicolumn{2}{c}{ Nucleotide diversity (h) } \\
\cline { 2 - 3 } & Cytochrome $-\boldsymbol{b}$ & \multicolumn{1}{c}{ RAG2 } \\
\hline Batanghari & 0.0002473821 & 0.0001077742 \\
Tulang Bawang & 0.0001250855 & 0 \\
Musi & 0.0005951715 & 0.0002083333 \\
Kapuas & 0.0002157268 & 0 \\
\hline
\end{tabular}


Table 3. Genetic distance of Chromobotia macracanthus populations based on mtDNA Cytochrome b

\begin{tabular}{lcccc}
\hline \multicolumn{1}{c}{ Population } & Batanghari & Tulang Bawang & Musi & Kapuas \\
\hline Batanghari & - & 0.0014093826 & 0.0026457524 & 0.0629659173 \\
Tulang Bawang & 0.0014093826 & - & 0.0027173587 & 0.0633613309 \\
Musi & 0.0026457524 & 0.0027173587 & - & 0.0643429202 \\
Kapuas & 0.0629659173 & 0.0633613309 & 0.0643429202 & - \\
\hline
\end{tabular}

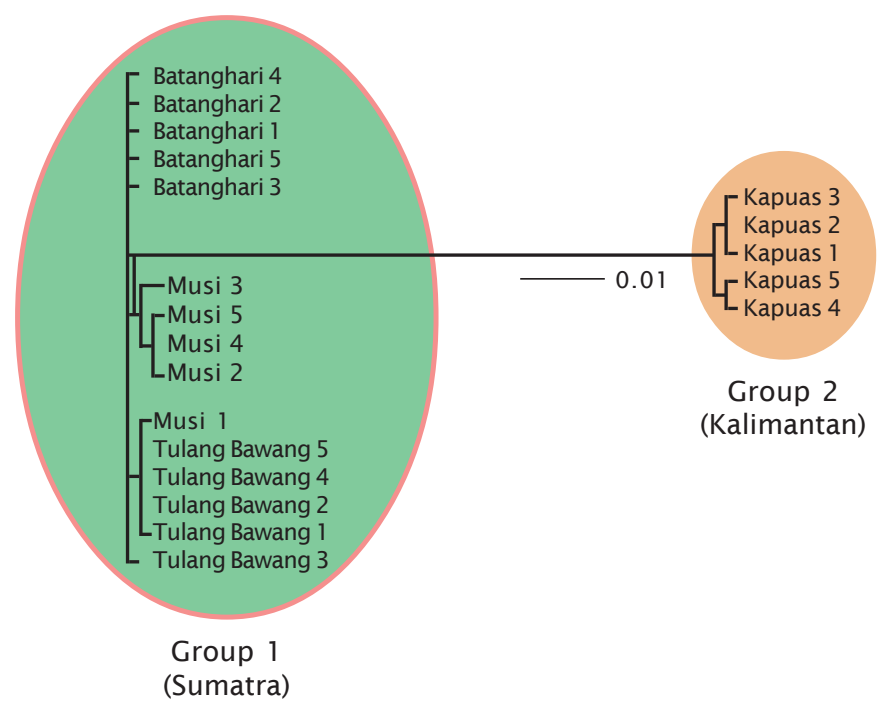

Figure 5. Neighbor-joining tree of Chromobotia macracanthus based on mtDNA Cytochrome b

Table 4. Genetic distance (average) inter population Chromobotia macracanthus based on RAG2

\begin{tabular}{lcccc}
\hline \multicolumn{1}{c}{ Population } & Batanghari & Tulang Bawang & Musi & Kapuas \\
\hline Batanghari & - & 0.0004873097 & 0.0006173712 & 0.0061945706 \\
Tulang Bawang & 0.0004873097 & - & 0.0003250382 & 0.0057036724 \\
Musi & 0.0006173712 & 0.0003250382 & - & 0.0060312396 \\
Kapuas & 0.0061945706 & 0.0057036724 & 0.0060312396 & - \\
\hline
\end{tabular}

genetically separated. The genetic distances among botia populations from Sumatra are relatively close, while the genetic distances among each population of Sumatra and Kalimantan have much longer distance.

\section{Neighbor-joining tree Based on Nucleus DNA RAG2}

The neighbor-joining tree using APE pro- gram (Paradis et al., 2004) based on nucleus DNA RAG2 is presented in Figure 6.

Based on the neighbor-joining tree of Chromobotia macracanthus, it supports the previous analysis that the population of botia is divided into two groups, namely group of Sumatra and group of Kalimantan which are separated from one to another as shown in Figure 6. 


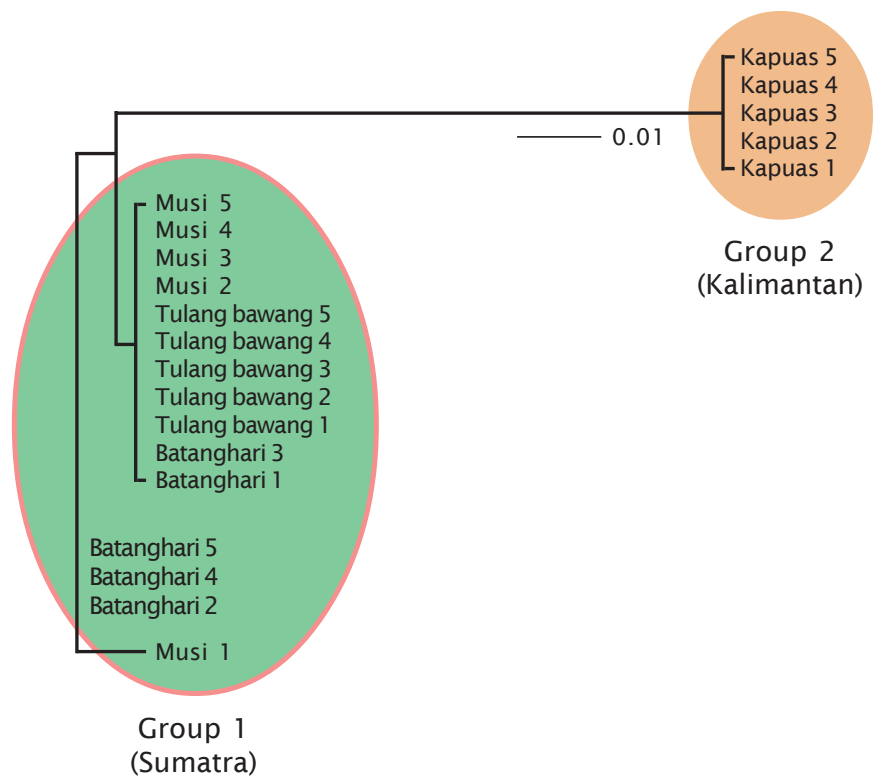

Figure 6. Neighbor-joining tree of Chromobotia macracanthus based on nucleus DNA RAG2

\section{DISCUSSION}

\section{Genetic Differentiation}

The sequencing result of DNA, mtDNA Cytochrome $b$ has higher nucleotide diversity than nucleus DNA RAG2 because the mutation rate of $m t D N A$ is relatively faster than nucleus DNA.

The Musi population has higher nucleotide diversity; nucleotide diversity for nucleus DNA RAG2 is only present on Batanghari and Musi populations, while Tulang Bawang and Kapuas populations are homogenous. The high genetic diversity between Musi and Batanghari populations may be influenced by the habitat of both populations which inhabit big river systems, as it was stated by Kusumah (2007).

Population of Tulang Bawang has low genetic diversity because Tulang Bawang River is a small river system in Sumatra. A small river system also indicates that it has small population. In small population, genetic drift has bigger role in degrading or deleting some of genetic diversity of population than in big population (Frankham et al., 2002).

Population of Kapuas also has low genetic diversity. It indicates that there were bottleneck effects in long time ago which affected the genetic drift, as stated by Kusumah (2007). This low genetic diversity is also caused by population restriction that happened long time ago that forced parts of population separated from the main population.

Based on mtDNA Cytochrome b, populations of Kapuas and Sumatra have long genetic distances, it ranges between 0.0629659173 (Kapuas and Batanghari) and 0.0643429202 (Kapuas and Musi). In addition, the genetic distance based on nucleus DNA RAG2 showed long genetic distance between Kalimantan and Sumatra populations (see Table 3). It indicates that both population groups may have been separated for a long time.

The botia populations of Sumatra based on mtDNA Cytochrome $b$ and nucleus DNA RAG2 have close genetic distance, it ranges between 0.0014093826 and 0.0027173587 (Table 3).

Musi and Tulang Bawang populations have close genetic distance $(0.0027173587$ on mtDNA Cytochrome $b$, and 0.0003250382 on nucleus DNA RAG2). It is suggested that Musi and Tulang Bawang may have merged before.

Neighbor-joining tree Chromobotia macracanthus based on mtDNA Cytochrome $b$ and nucleus DNA RAG2 showed that there were two groups of botia population namely 
population group of Sumatra (Musi, Batanghari, Tulang Bawang) and population group of Kalimantan (Kapuas).

\section{Time Divergence and Speciation Process}

The mutation rate on mtDNA Cytochrome $b$ is faster than that of nucleus DNA (Baker, 2000). Time divergence for Cobitis (family: Cobitidae) based on the mtDNA Cytochrome $b$ gene is $0,68 \%$ per pairwise per one million year (Doadrio $\&$ Perdices, 2005). Based on this result, time divergence rate and time divergence between populations of Kalimantan and Sumatra can be calculated. Genetic distance among population of Kalimantan and Sumatra based on mtDNA Cytochrome b is 6.29\%-6.43\%, which means that the time divergence between populations of Kalimantan and Sumatra is about 9.25-9.46 million years ago (Miocene era).

The previous study (Kusumah, 2007) showed that the botia populations of Sumatra and Kalimantan have some common alleles. It means that the two populations have merged long time before. Kottelat et al. (1993) stated that Kalimantan, Sumatra, Java, and Malayan Peninsula merged into one mainland with Sunda shelf in pleistocene era $(10,000-$ $2,000,000$ years ago). Although the rivers in Sumatra (Musi and Batanghari) merged with Kapuas river into one river system that flown into South China Sea (Figure 7), there was no genetic evidence about the mix between the two populations during the glacial times. Environmental factors such as acidity, conductivity, water depth, salinity or vegetation covering the area could become the barrier for both population groups to mix each other.

Musi and Batanghari River once merged into one ancient river system that flown into South China Sea (Kottelat et.al., 1993; Voris, 2000). The rising of the sea level due to melting ice on the last pleistocene era caused the singking of this ancient river system; both Musi and Batanghari were finally separated in different river system up until now.

Although Musi and Tulang Bawang Rivers have never merged into one river system since pleistocene era, both of botia populations have little genetic differences based on mtDNA Cytochrome $b$ and nucleus DNA RAG2. It means that botia populations in Musi and Tulang Bawang rivers have once merged. Perhaps both of populations mixed on the flood plain area during wet season as stated by Kusumah (2007).

\section{Population Management of Botia}

Population genetic has an important role in fisheries management because the genetic resources determine the fitness of a population and it is an important key for species to survive for generations (Soewardi, 2007).

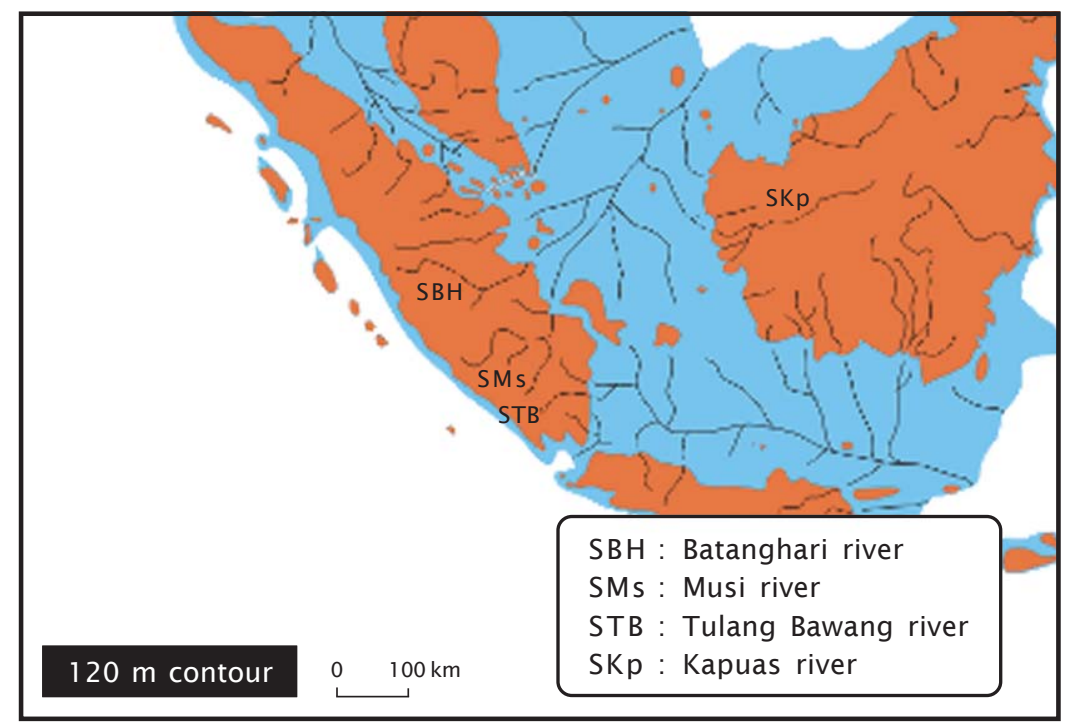

Figure 7. Map of ancient river systems in pleistocene era (Voris, 2000) 
Therefore conservation on genetic resources becomes the primary interest for IUCN (International Union for Conservation of Nature and Natural Resources).

The result showed that there was low genetic diversity in botia populations of Kapuas. Therefore, it is needed to increase the genetic diversity to conserve the botia population of Kalimantan. The result also showed that there are big genetic differences between population group of Sumatra with population group of Kalimantan. The restocking effort for population of botia can not be done by importing botia populations from Sumatra to Kalimantan and vice versa. The botia population of Sumatra can not live in the original habitat of botia Kalimantan, and if the could, it may disturb the genetic diversity of botia populations in Kalimantan.

Besides, the botia of Sumatra lives well in $\mathrm{pH}$ 6,8--7 (Lesmana, 2002), while the $\mathrm{pH}$ of Kapuas river is around 6,1--6,5 (Yulistiana, 2007). The $\mathrm{pH}$ difference among Sumatra and Kalimantan will probably cause botia population from Sumatra cannot survive in Kalimantan.

In order to increase botia population of Kalimantan, the artificial selection is needed. The artificial selection can be done by breeding the botia of Kapuas with other botia populations from Kalimantan such as botia from Mahakam River.

\section{CONCLUSION AND SUGGESTION}

The sequencing result of DNA shows that mtDNA Cytochrome $b$ has higher nucleotide diversity than that of nucleus DNA RAG2 because the mutation rate of $m$ tDNA is relatively faster than nucleus DNA.

The populations from Sumatra (Musi, Batanghari, and Tulang Bawang) and Kalimantan (Kapuas) have long genetic distance, it is then suggested that the botia population in Kalimantan probably is considered as a distinct species.

Previous studies showed that the botia populations of Sumatra and Kalimantan have some common alleles which means that the two populations might have once merged long time before. Based on mtDNA Cytochrome $b$ sequencing, the time divergence between population group of Sumatra and Kalimantan is about 9,25--9,46 million years ago (miocene era).
The clear genetic differentiation between population groups of Sumatra and Kalimantan give important information for the future management of botia population. In order to strengthen the conclusion that the botia population from Kalimantan is a distinct species, further research has to be done by collecting some more samples of botia populations from other different river systems in Kalimantan.

\section{REFERENCES}

Baker, A.J., editor. 2000. Molecular methods in ecology. Oxford: Blackwell Science.

Doadrio, I. and A. Perdices. 2005. Phylogenetic relationships among the Ibero-African cobitids (Cobitis, Cobitidae) based on cytochrome b sequence data. Molecular Phylogenetic Evolution. 37: 484-493.

Dunham, R.A. 2004. Aquaculture and fisheries biotechnology: Genetic Aprroaches. CABI Publishing.

Frankham, R., J.D. Ballou, and D.A. Briscoe. 2002. Introduction to conservation genetics. Cambridge University Press.

Griffiths, R.C., M. Bahlo, and S. Tavare. 2000. Inference from gene trees in a subdivided population-theory. Population Biology. 57(2): 79-95.

Gustiano, R. 2003. Taxonomy and phylogeny of pangasiidae catfishes from Asia (Ostariophysi, Siluriformes). Katholieke Universteit Leuven, Belgia.

Harteman, E. 1998. Afinitas komunitas ikan dengan habitat di Sungai Kapuas, Kabupataen Kapuas, Kalimantan Tengah. [tesis]. Program Pasca Sarjana. Institut Pertanian Bogor.

Kimura, M. 1980. Estimation of evolutionary distance between homologous nucleotide sequences. Genetics. 78: 454--458.

Kimura, M. 1981. A Model of evolutionary base substitution and its application with special reference to rapid change of Pseudogenes. Genetics. 98: 641--657.

Kottelat, M., A.J. Whitten, S.N. Kartikasari, dan S. Wirjoatmodjo. 1993. Ikan air tawar Indonesia bagian barat dan Sulawesi. Hong Kong: Periplus Editions. 259 pp.

Kottelat, M. 2004. Botia kubotai, A New species of Loach (Teleostei: Cobitidae) from the Ataran river basin (Myanmar), with comments on botiinae nomenclature and diagnosis of a new genus. Singapura: National University of Singapore. S. 
Kusumah, R.V. 2007. Struktur populasi dan sejarah kolonisasi ikan botia (Chromobotia Macracanthus Bleeker) berdasarkan sequence (urutan basa) intron dari gen aldolase $b$ [skripsi]. Fakultas Perikanan dan IImu Kelautan. Institut Pertanian Bogor.

Lemire, B. 2005. Mitochondrial genetics. [serial online]. http://www.wormbook.org/. [22 Maret 2007].

Lesmana, D.S. 2002. Kualitas air untuk ikan hias air tawar. Jakarta: Penebar Swadaya. 317 pp.

NCBI. 2007. [Serial online]. http://www.ncbi. nIm.nih.gov/entrez/viewer. fcgi?db=nucleotide \& val=1 19360455. [12 April 2007]

Nei, M. 1987. Molecular evolutionary genetics. New York: Columbia University Press.

Oulu. 2000. Phylogeny and phylogeography of European Parids [serial online]. http:// herkules.oulu.fi/ISBN9514255364/. [25 April 2007].

Paradis, E., J. Claude, and K. Strimmer 2004. APE: analyses of phylogenetics and evolution in R language. Bioinformatics. 20(2): 289-290.

Pouyaud, L., Sudarto, and G. Teugels. 2003. The different colour varieties of the Asian arowana Scleropages formosus (Osteoglossidae) are distinct species: morphologic and genetic evidences. Cybium. 27(4): 287--305.

Randi, E. 2000. Mitochondrial DNA. di dalam: Baker, Allan J., editor. Molecular Methods In Ecology. Oxford : Blackwell Science. p. 136--167.

Rina. 2001. Keragaman genetik ikan pangasius Indonesia berdasarkan analisa DNA mitokondria dengan teknik PCR-RFLP [tesis]. Program Pasca Sarjana. Institut Pertanian Bogor.

Saitou, N. dan M. Nei. 1987. The Neighbor-joining Method: A new method for reconstructing phylogenetic trees. Molecular Biology and Evolution 4: 406-425.

Šlechtová, V. et al. 2006. Molecular phylogeny of southeast asian freshwater family Botiidae (Teleostei : Cobitidae) and the ori- gin of polyploidy in their evolution. Molecular Genetics and Evolution. 30 pp.

Soewardi, K. 2002. Peranan genetika populasi dalam pengelolaan sumberdaya hayati kelautan. Departemen Manajemen Sumberdaya Perairan. Fakultas Perikanan dan IImu Kelautan. IPB. (tidak dipublikasikan).

Soewardi, K. 2007. Pengelolaan keragaman genetik sumberdaya perikanan dan kelautan. Departemen Manajemen Sumberdaya Perairan. Fakultas Perikanan dan Ilmu Kelautan. Institut Pertanian Bogor. $153 \mathrm{pp}$.

Sullivan, J., S. Lavoue, and C. Hopkins. 2000. Molecular syastematics of the African electric fishes (Mormyroidea: Telestoi) and a model for the evolution of their electric organs. Journal of the experimental Biology. 203: 665--683.

Utami, E. 2003. Pengaruh derajat keasaman air yang berbeda terhadap laju pertumbuhan dan kelangsungan hidup benih ikan botia (Botia macracanthus Bleeker). [skripsi]. Fakultas Perikanan dan ilmu Kelautan. Institut Pertanian Bogor.

Voris, H.K. 2000. Maps of pleistocene sea levels in Southeast Asia: Shorelines, River Systems and Time Durations. Journal of Biogeography. 27: 1,153-1,167.

Weber, M. and L.F. de Beaufort. 1916. The fishes of the Indo-Australian archipelago. Vol VIII. E. J. Brill, Ltd. Leiden. $456 \mathrm{pp}$.

Wiley, E.O. 1981. The theory and practice of phylogenetic systematics. Canada: John Wiley \& Sons.

Wirasatya, H. 1994. Penelaahan beberapa karakteristik biologi populasi ikan botia (Botia macracanthus Bleeker) di Sungai Batanghari dan Sungai Kapuas. Skripsi. Bogor :Institut Pertanian Bogor.

Wikipedia.2007. RAG.[serialonline].http:// www.wikipedia.org/wiki/RAG.html. [01 Maret 2007].

Yulistiana, L. 2007. Penentuan kualitas air dan kajian daya tampung Sungai Kapuas, Kota Pontianak. [Tesis]. Sekolah Pasca Sarjana. Institut Pertanian Bogor. 